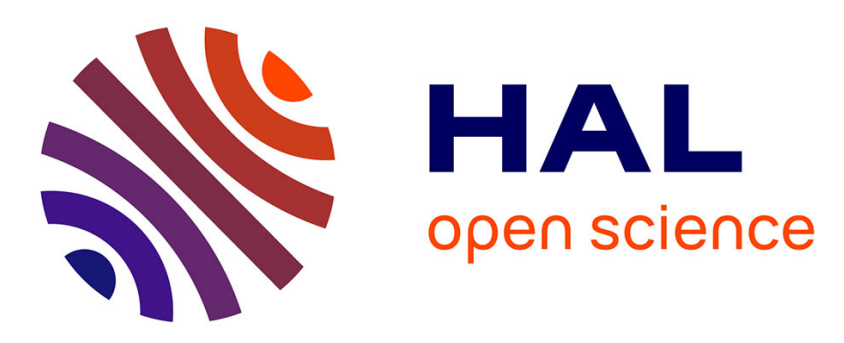

\title{
Plasma cells release membrane microparticles in a mouse model of multiple myeloma.
}

\author{
Tarek Benameur, Daniel Chappard, Elodie Fioleau, Ramaroson \\ Andriantsitohaina, M. Carmen Martínez, Nicolas Clere, Hélène \\ Marchand-Libouban
}

\section{To cite this version:}

Tarek Benameur, Daniel Chappard, Elodie Fioleau, Ramaroson Andriantsitohaina, M. Carmen Martínez, et al.. Plasma cells release membrane microparticles in a mouse model of multiple myeloma.. Micron, 2013, 54-55, pp.75-81. 10.1016/j.micron.2013.08.010 . hal-03262104

\section{HAL Id: hal-03262104 \\ https://univ-angers.hal.science/hal-03262104}

Submitted on 16 Jun 2021

HAL is a multi-disciplinary open access archive for the deposit and dissemination of scientific research documents, whether they are published or not. The documents may come from teaching and research institutions in France or abroad, or from public or private research centers.
L'archive ouverte pluridisciplinaire HAL, est destinée au dépôt et à la diffusion de documents scientifiques de niveau recherche, publiés ou non, émanant des établissements d'enseignement et de recherche français ou étrangers, des laboratoires publics ou privés. 


\title{
Plasma cells release membrane microparticles in a mouse model of multiple myeloma
}

\author{
Tarek Benameur ${ }^{\mathrm{a}, \mathrm{b}}$, Daniel Chappard ${ }^{\mathrm{a}, \mathrm{c}}$, Elodie Fioleau ${ }^{\mathrm{a}, \mathrm{c}}$, \\ Ramaroson Andriantsitohaina ${ }^{\mathrm{a}, \mathrm{b}}$, M. Carmen Martinez ${ }^{\mathrm{a}, \mathrm{b}}$, \\ Nicolas Clere $^{\mathrm{a}, \mathrm{b}}$, Hélène Marchand-Libouban ${ }^{\mathrm{a}, \mathrm{c}, *}$ \\ a L'UNAM Université, Angers, France \\ b INSERM U1063, Angers, France

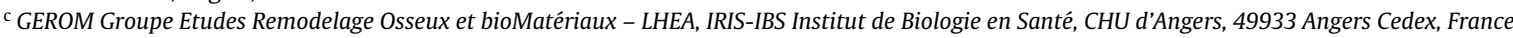

\section{A R T I C L E I N F O}

\section{Article history:}

Received 4 June 2013

Received in revised form 28 August 2013

Accepted 28 August 2013

\section{Keywords:}

Multiple myeloma

Microparticles

Plasma B cells

Microenvironment

CD138

\begin{abstract}
A B S T R A C T
Microparticles (MPs) released from the plasma membrane play a role in tumor progression. Involvement of MPs in myeloma (MM) has been poorly investigated. Because of the strong interaction of MM cells with bone microenvironment, we hypothesized an implication of MPs in MM using a murine model. Forty-four mice were injected with 5THL-MM cells and compared with 14 non-injected mice. Blood was collected at the early and end stages of MM development (EMM and LMM) to characterize the circulating MPs. At LMM, MPs were isolated from bone marrow (BM) of long bones of 22 mice, after centrifugation. Electron microscopy immunohistochemistry and Western blotting using CD138 were performed on BMderived MPs. At EMM, MPs circulating level was significantly lower versus controls. In LMM, a significant increase of the total MP number from plasma was observed versus controls. Characterization of circulating MPs showed an increase of leukocyte- and erythrocyte-derived MPs. In LMM, serum M-protein was correlated with circulating MP number. BM-derived MPs increased in LMM and expressed CD138. AntiCD138 coupled with nanobeads localized at the MP surface. There is evidence of an association between increase of MPs and MM development; the results underscore the participation of plasma cell-derived MPs originating from BM.
\end{abstract}

(c) 2013 Elsevier Ltd. All rights reserved.

\section{Introduction}

Multiple myeloma (MM) is a B cell malignancy characterized by monoclonal proliferation of plasma cells in the local bone marrow (BM) environment and the development of osteolytic bone lesions. The BM microenvironment has a key role in MM as it includes a large spectrum of cellular and molecular components that influence plasma cells growth and osteolysis (Asosingh et al., 2003; Lemaire et al., 2011). A true "cious circle" exists where plasma cells stimulate bone and medullar cells which stimulate in return the neoplastic growth. Demonstration that the growth of malignant plasma cells is accelerated with a pre-existing high level of bone remodeling has been shown using a combined animal model in which ovariectomy was associated to injection of 5T2MM plasma cells in the C57BL/KaLwRij mouse (Libouban et al., 2003). Osteoclasts respond to a variety of cytokines and growth

\footnotetext{
* Corresponding author at: GEROM - LHEA, IRIS-IBS, CHU d'Angers, 49933 Cedex, France. Tel.: +3324468 8344 .

E-mail address: helene.marchand-libouban@univ-angers.fr (H. Marchand-Libouban).
}

factors produced by cells of the BM microenvironment and by the malignant plasma cells. These factors include macrophage inflammatory protein-1-alpha (MIP-1 $\alpha$ ), the ligand for receptor activator of nuclear transcription factor- $\mathrm{KB}$ (RANKL) and interleukin-3 (IL3) (Asosingh et al., 2003; Choi et al., 2000; Lee et al., 2004; Pearse et al., 2001). It is now well recognized that a decrease of bone formation plays also a key role in MM. Inhibition of osteoblastogenesis is due to osteoblast inhibitors released by plasma cells including Wnt-signaling inhibitors Dickkopf-1 (DKK1) and Secreted frizzledrelated protein 2 (Sfrp2), hepatocyte growth factor (HGF) and IL-7 (Giuliani et al., 2005; Oshima et al., 2005; Standal et al., 2007; Tian et al., 2003). Cells involved in the "vicious circle" are of hematological origin at various differentiation stages, BM stromal cells, endothelial and bone cells (osteoblasts and osteoclasts) (Mitsiades et al., 2007). Interaction with endothelial cells mainly supports tumor growth and neoangiogenesis is observed in MM (Roccaro et al., 2006). More recently, interactions with T- and dendritic cells (Giuliani et al., 2006; Kukreja et al., 2006) were revealed thus amplifying the "vicious circle". Thus, MM appears as an excellent model for studying tumor-microenvironment. Implication of the microenvironment interactions in the development of a tumor has been shown in other type of cancers. 
Recently, another mechanism has been highlighted in inducing a favorable local microenvironment for tumor growth: membranederived vesicles (MPs) shed from different cell types (Peinado et al., 2011). MPs are membrane-derived vesicles (diameter $\leq 1 \mu \mathrm{m}$ ) that are released during cell activation or apoptosis. On their surface, MPs bear antigens characteristic of the cell of origin, and carry other membrane and cytoplasmic constituents. MPs are present in blood from healthy and non-healthy individuals leading to the hypothesis that they may play physiological and/or pathophysiological roles. Previous studies have revealed various roles of MPs in cancer. It has been recently shown that MPs can induce in vitro neo-angiogenesis which might contribute to the generation of a vascular network in malignant disease associated with tumor growth (Soleti et al., 2009). In addition, MPs released from tumor cells have a pro-angiogenic activity (Kim et al., 2002). Other membrane compounds linked to MPs, such as urokinase, can increase the invasive capacity of prostate cancer cells (Angelucci et al., 2000). MPs are able to carry intercellular signals allowing the tumor survival and progression. Considering that enhanced levels of circulating MPs have been detected in patients with different types of cancers, one can advanced the hypothesis that MPs might play an important role in the tumor development (Martinez and Andriantsitohaina, 2011; Mostefai et al., 2008; Tual-Chalot et al., 2011).

Because of the various cell types involved in MM and the strong interaction of the bone and medullar microenvironment, we hypothesized an implication of MPs in the development of MM. In the present study, quantification and characterization of both circulating-MPs and BM-derived MPs were investigated in the 5THL murine model of MM.

\section{Materials and methods}

\subsection{Mice}

C57BL/KaLwRij female mice (6-8-week-old) were used for the study (Harlan, Gannat, France). They were acclimated for 1 week to the local vivarium conditions $\left(24^{\circ} \mathrm{C}\right.$ and $12 \mathrm{~h} / 12 \mathrm{~h}$ light/dark cycle) where they were given standard laboratory food (UAR, Villemoison sur Orge, France) and water ad libitum. The Animal Care and Use committee at the University of Angers approved all procedures.

\subsection{Culture cell line}

We have used the 5THL cell line as previously characterized (Libouban et al., 2004). Briefly, the 5THL cell line is an aggressive subline of 5T2MM cell line originating from elderly C57BL/KaLwRij mice that spontaneously developed MM (Croese et al., 1987). 5THL cells can be propagated into young syngeneic mice by intravenous transfer of the diseased BM. Progression of the disease in seven recipient mice was assessed by measuring the serum $M$-protein (IgG2aк) level using agar electrophoresis (Hydragel Protein, SEBIA, Issy les Moulineaux, France). Around 6 week post-injection of 5THL, mice had a detectable serum M-protein and were euthanized after $10-12$ weeks by cervical dislocation. Femurs and tibias were dissected, cleaned of surrounding tissues and BM was flushed in Dulbecco's modified essential medium (DMEM.mod, GIBCO, Life Technologies, France) supplemented with penicillin-streptomycin, amphotericin-fungizone and pyruvate. BM cells were washed once in DMEM.mod. Mononuclear cells were isolated by a Lympholyte$M$ centrifugation gradient (Cedarlane, Hornby, Ontario, Canada) at $1250 \times g$ for $20 \mathrm{~min}$. Mononuclear cells were then washed twice in DMEM.mod and counted.

\subsection{Experimental design}

Forty-four mice (6-8 weeks old) were injected with $1.5 \times 10^{6}$ 5THL cells in the tail vein and 14 non-injected mice were used as control (CTL). The injected mice were divided in 2 groups according to the time of sacrifice. At 6 weeks, corresponding to the early stage of MM development, 14 mice were bled before being sacrificed by cervical dislocation. These mice constituted the early stage MM group (EMM) and were used to quantify and characterize the phenotype of circulating MPs. At the end stage of the disease (10-12 weeks), when osteolysis can be evidenced on X-ray images, the remaining 30 mice were bled before being sacrificed by cervical dislocation. These mice constituted the late stage MM group (LMM) and were used to quantify and characterize the phenotype of circulating MPs (see below). Twenty-two mice from the LMM group were also used to isolate MPs from the BM of femurs and tibias. The 14 non-injected mice (16-18-week-old) were bled as previously described to quantify and phenotype circulating MPs. Eight of the 14 mice were also used to isolate MPs from BM.

Two additional mice injected with 5THL cells were sacrificed at the end stage of the disease and were used for transmission electron microscopy (TEM) observations and immunohistochemistry of BMderived MPs and MM cells.

\subsection{Circulating MP isolation and characterization}

C57BL/KaLwRij mice at 6 weeks or at 10-12 weeks were anesthetized using Isoflurane (Baxter, Maurepas, France) before sacrifice, and $\sim 800 \mu \mathrm{l}$ of blood were collected by aspiration from the left ventricle. Blood was placed in citrated tubes and centrifuged at $1900 \times g$ for $3 \mathrm{~min}$ for separation of platelet-rich plasma from whole blood. Then, platelet-rich plasma was centrifuged at $5000 \times g$ for $4 \mathrm{~min}$ to obtain platelet-free plasma (PFP). Sixty microliters of PFP were frozen and stored at $-80^{\circ} \mathrm{C}$ until subsequent use. In order to pellet MPs for in vitro studies, circulating MPs were concentrated from PFP by three series of centrifugations at $21,000 \times \mathrm{g}$ for $45 \mathrm{~min}$ and re-suspended in saline and stored at $4{ }^{\circ} \mathrm{C}$ until subsequent use.

Membrane MP subpopulations were discriminated in PFP according the expression of membrane-specific antigens. Phenotype of endothelial MPs was performed using anti-CD54 labeling; characterization of platelet, leukocyte and erythrocyte MPs was performed using respectively anti-CD61, anti-CD45 and Ter119/erythroid cell labeling. Irrelevant mouse IgG was used as an isotype-matched negative control for each sample.

For numeration studies, $8 \mu$ l of PFP were incubated with either $1 \mu \mathrm{l}$ of specific antibody (BioLegend, San Diego, CA). After 45 min of incubation at room temperature, samples were diluted in $300 \mu \mathrm{l}$ of saline. Annexin V (BioVision, Inc., Mountain View, CA) binding was used to numerate circulating phosphatidylserine-expressing MPs ( $2 \mu \mathrm{l}$ of annexin V/5 $\mu \mathrm{l}$ PFP). Then, in order to enumerate MPs, an equal volume of sample and Flowcount beads were added and samples were analyzed in a flow cytometer 500 MPL system (Beckman Coulter, Roissy, France) as previously described (Agouni et al., 2008; Mostefai et al., 2008). Flow-count fluorospheres consist of $10 \mu \mathrm{m}$ polystyrene fluorospheres in an aqueous suspension medium. Each fluorosphere contains a dye that has a fluorescence emission range of $525-700 \mathrm{~nm}$ when excitated at $488 \mathrm{~nm}$. The concentration of each lot of Flow-count fluorospheres is derived from multiple replicate analyses on a COULTER particle size analyzer performed by the manufacturer. Each lot of Flow-count fluorospheres has a specific concentration of fluorospheres. When identical volumes of a sample and Flow-count fluorospheres are used, a ratio of MPs in the sample to fluorospheres is established. Since the concentration of fluorospheres is known, the absolute count of the MPs can be automatically determined by the MXP software. 


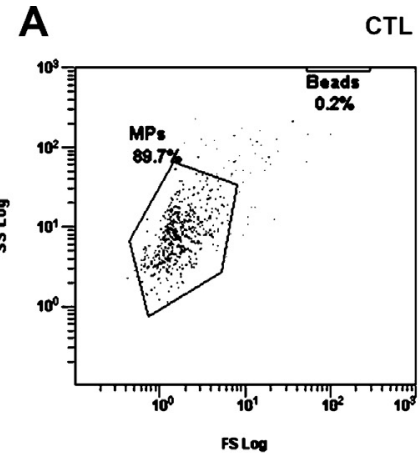

B

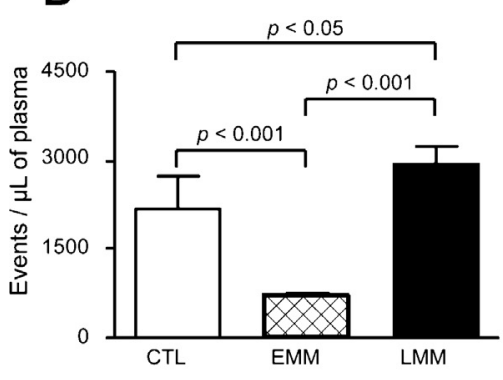

E

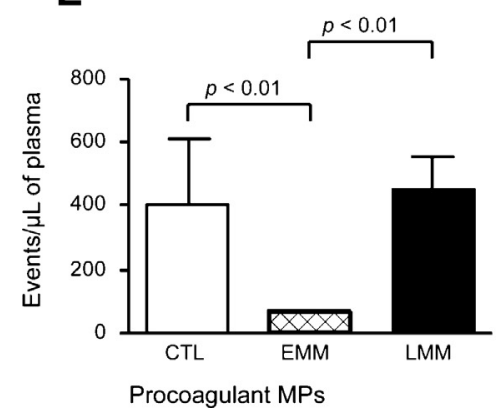

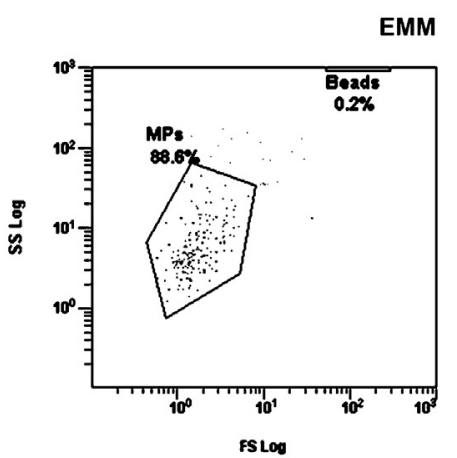

C

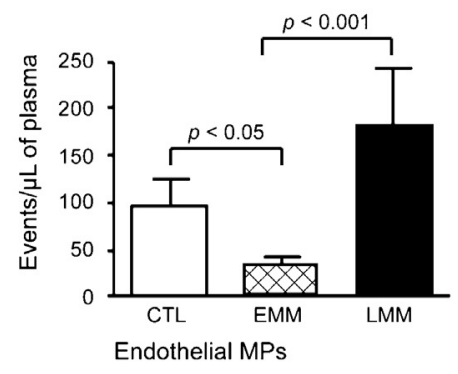

$\mathbf{F}$

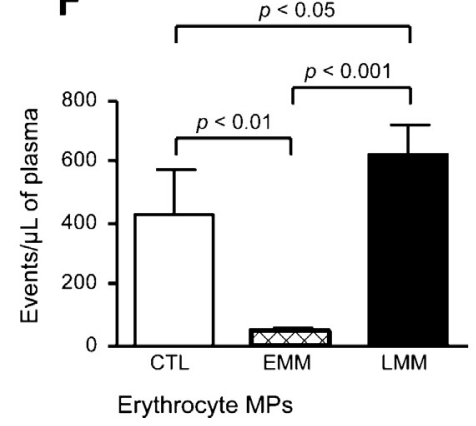

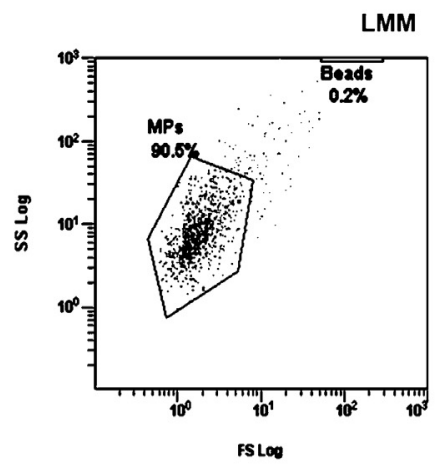

D
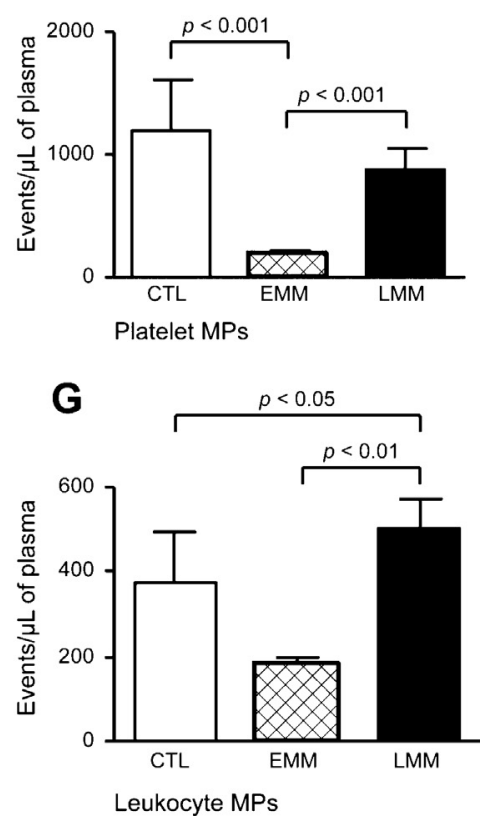

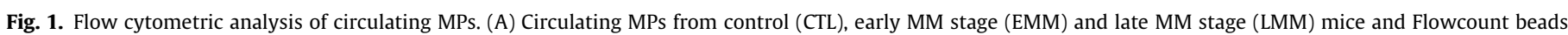

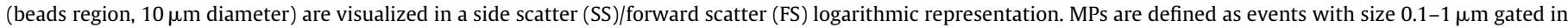

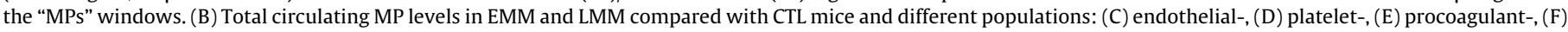

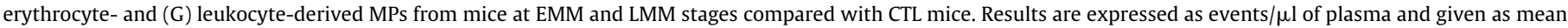
SEM.

\subsection{Bone marrow (BM)-derived MP isolation}

BM cells from 5THL-MM and control mice (10-12 weeks) were flushed from long bones and centrifuged; supernatant was used to isolate MPs. Briefly, femurs and tibias were dissected, cleaned of surrounding tissues and BM was flushed in DMEM.mod supplemented with penicillin-streptomycin, amphotericin-fungizone and pyruvate. Cell suspension $(\sim 8 \mathrm{ml})$ was filtered and centrifuged at $300 \times g$ for $5 \mathrm{~min}$. MPs were isolated from supernatants, collected and cleared from detached cells or large cell fragments by centrifugation as described above. The washing medium from the last supernatant was used as control.

\subsection{Western blotting at end stage of disease}

Protein analysis by Western blotting was performed on homogenized MPs obtained from BM of 2 mice. Because plasma cells are a subpopulation of leukocytes expressing heterogeneously CD45 and more specifically CD138 (syndecan-1), we used an anti CD138 monoclonal antibody (Wijdenes et al., 2002). Total protein of
BM-derived MPs from 5THL-MM mice $(20 \mu \mathrm{g})$ were probed with rat anti-CD138 (BD Biosciences, San José, CA, Ref. 553712).

\subsection{Transmission electron microscopy and immunohistochemistry}

Cells and MPs were fixed with a freshly prepared $2 \%$ paraformaldehyde in $0.1 \mathrm{M}$ sodium cacodylate buffer $(\mathrm{pH} 7.4)$ for $1 \mathrm{~h} 30 \mathrm{~min}$ at $20^{\circ} \mathrm{C}$. They were then dehydrated in grading concentration of ethanol between $-20^{\circ} \mathrm{C}$ and $-40^{\circ} \mathrm{C}$. Embedding was done in Lowicryl K4M (Polysciences, Paris) and polymerized at $-40^{\circ} \mathrm{C}$ by UV light ( $\lambda=360 \mathrm{~nm}$ ) (AFS, Leica). Sections of $60 \mathrm{~nm}$ in thickness were performed using an Ultracut S microtome (Leica Ultracut E) and collected on copper grids.

After rinsing with PBS buffer, grids were incubated in $50 \mathrm{mM}$ $\mathrm{NH}_{4} \mathrm{Cl}$ followed by $1 \%$ bovine albumin. Goat polyclonal anti-mouse CD138 antibody (R\&D Systems, France Ref. AF-3190) was used as the primary antibody (dilution 1/50 in PBS buffer, incubation $1 \mathrm{~h}$ $30 \mathrm{~min}$ ). After several rinses in PBS, grids were incubated for $30 \mathrm{~min}$ with the secondary antibody IgG anti-goat coupled with colloidal gold particles (10 nm in diameter, Sigma Ref. G-5402). Grids were 
rinsed with PBS, contrasted with uranyl acetate (saturated in distilled water) and observed with a JEOL 2010 TEM under $200 \mathrm{kV}$ voltage.

\subsection{Statistical analysis}

Statistical study was done with SYSTAT statistical software (Systat, San José, CA, release 13.0). All data were reported as mean \pm standard error of the mean (SEM). Significant differences between groups were analyzed by analysis of variance (ANOVA) with the Fisher's least significant difference post hoc test. In order to evaluate if correlations exist between the level of M-protein and the level of circulating MPs, a linear regression analysis was performed using 7 mice at the end stage of the disease; the Pearson's coefficient of correlation was determined. Results were considered as significant when $P<0.05$.

\section{Results}

3.1. Circulating levels of MPs at the end stage of MM compared with the early stage

Circulating levels of MPs were determined at the early (6 weeks) and at the end stages (10-12 weeks) of MM development (Fig. 1A-G). For each groups of mice (CTL, EMM and LMM), histograms/bivariate plots resulting from MPs enumeration are represented in Fig. 1A. At EMM, the total number of circulating MPs was significantly reduced by $\sim 30.5 \%$ compared to control mice (Fig. 1B). In contrast, at LMM, a significant increase of the total number of MPs from plasma was observed compared to control mice. Circulating level of MPs was found significantly higher at LMM compared to EMM.

Phenotypic characterization of the cellular origin of MPs showed significant increases of the circulating levels of MPs with a procoagulant potential (Annexin $\left.\mathrm{V}^{+}\right)$-, and those of platelet $\left(\mathrm{CD}^{+} 1^{+}\right)-$, leukocyte $\left(\mathrm{CD}^{+} 5^{+}\right)-$, endothelial $\left(\mathrm{CD} 54^{+}\right)$- and erythrocyte-derived MPs in MM mice at LMM compared with EMM (Fig. 1C-G). We found a significant correlation between the level of serum M-protein and the level of circulating MPs $(r=0.77 ; P<0.05)$ (Fig. 2$)$.

\subsection{Bone marrow levels of MPs at $L M M$}

Flow cytometer analysis revealed a significant increased ( $\sim 3.7$-fold, $P<0.05$ ) amount of MPs from BM in mice at LMM (Fig. 3) probably due to the increased number of cells into BM. Indeed, the enhanced production of MPs from BM was positively correlated with the number of BM-derived cells at LMM (Fig. 4) suggesting that elevated number of MPs results from enhanced cell count in BM and not from an increased ability of cells to vesiculate. The presence of MPs within the BM was clearly evidenced by TEM observation of isolated MPs; they are heterogeneous in size with a maximum $750 \mathrm{~nm}$ diameter (Fig. 5A).

\subsection{Expression of plasma cell biomarker CD138 on BM-derived MPs}

TEM immunochemistry showed the presence of several gold nanobeads around MPs; some being clearly localized at the surface of the MPs (Fig. 5B). Western blot revealed also the expression of the plasma cell marker CD138 (syndecan-1) by BMderived MPs from 2 mice at LMM (Fig. 5C). Gold nanobeads coupled with anti-CD138

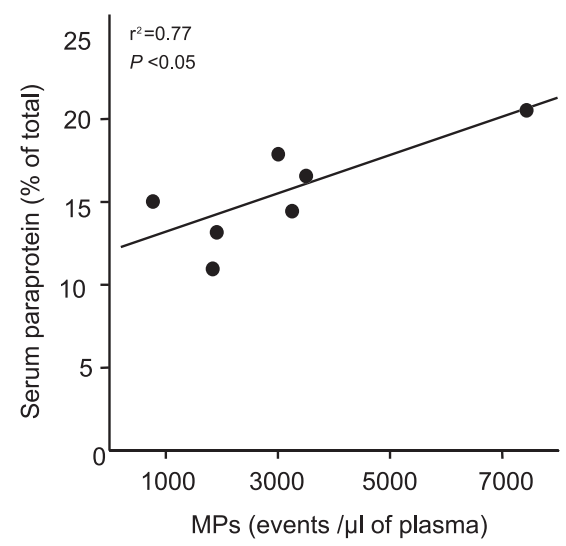

Fig. 2. Correlation between the level of serum M-protein and the level of circulating MPs.

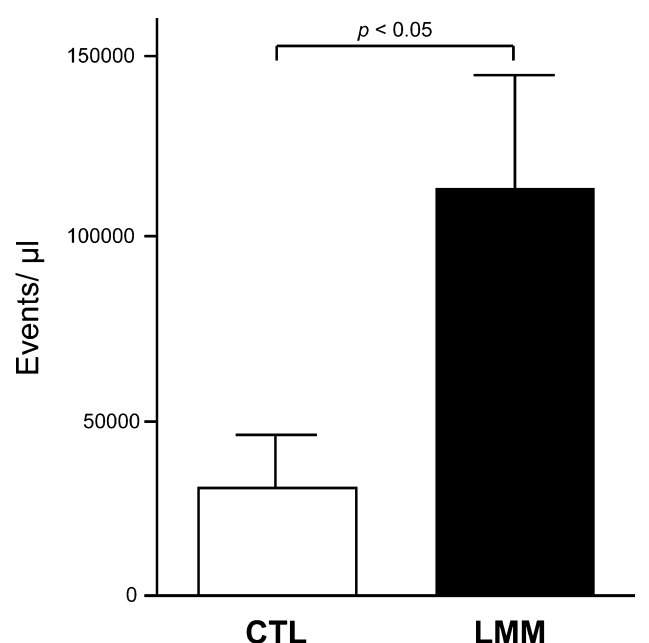

Fig. 3. Flow cytometry analysis of bone marrow-derived MPs. Bone marrow-derived MP levels were significantly increased at the late stage of MM (LMM) compared with control (CTL) mice.

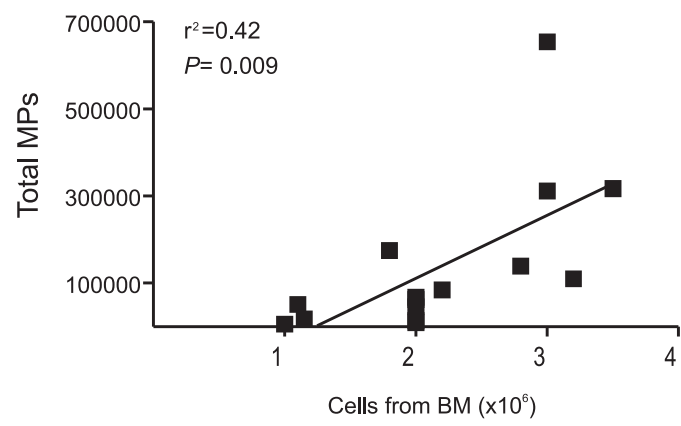

Fig. 4. Positive correlation between the total MPs and the number of cells derived from BM of 5THL-MM mice.

were also identified at the surface of 5THL cells (Fig. 5D) isolated from the same mice at the end stage of MM (Fig. 4E)

\section{Discussion}

The allograft of 5TMM cells in C57BL/KaLwRij mice is one of the main models to study the pathophysiology of MM, the influence of BM microenvironment on tumor progression and to evaluate drug effects on osteolysis and tumor growth (Asosingh et al., 2000). The 5T2MM represents a model situation of the most common forms of human MM disease, with a moderate growth and osteolytic lesions. In the present study, we used 5THL cells in which M-protein in was detected after 6 weeks and osteolysis detected after 8 weeks post-injection, as previously described (Libouban et al., 2004). It is well established that interactions exist between malignant plasma cells, BM stromal cells, osteoclast precursors and endothelial cells. Stromal cells play a key role in tumor progression as most of the factors involved in MM are released in the microenvironment due to molecular interactions with stromal cells (Abe et al., 2009; Michigami et al., 2000). The role of the microenvironment was proven by various studies in which a factor implicated in the MM vicious circle was inhibited: as an example, it was shown that inhibition of cell-cell contact (between MM and stromal cells) completely prevented the increase of resorption (Abe et al., 2004). Other studies showed that inhibition of osteoclastic activity considerably reduced tumor progression without a complete abolishing of the tumor growth (Croucher et al., 2003). Conversely, when using the 5T2MM model, we showed that a favorable microenvironment can enhance tumor growth and 

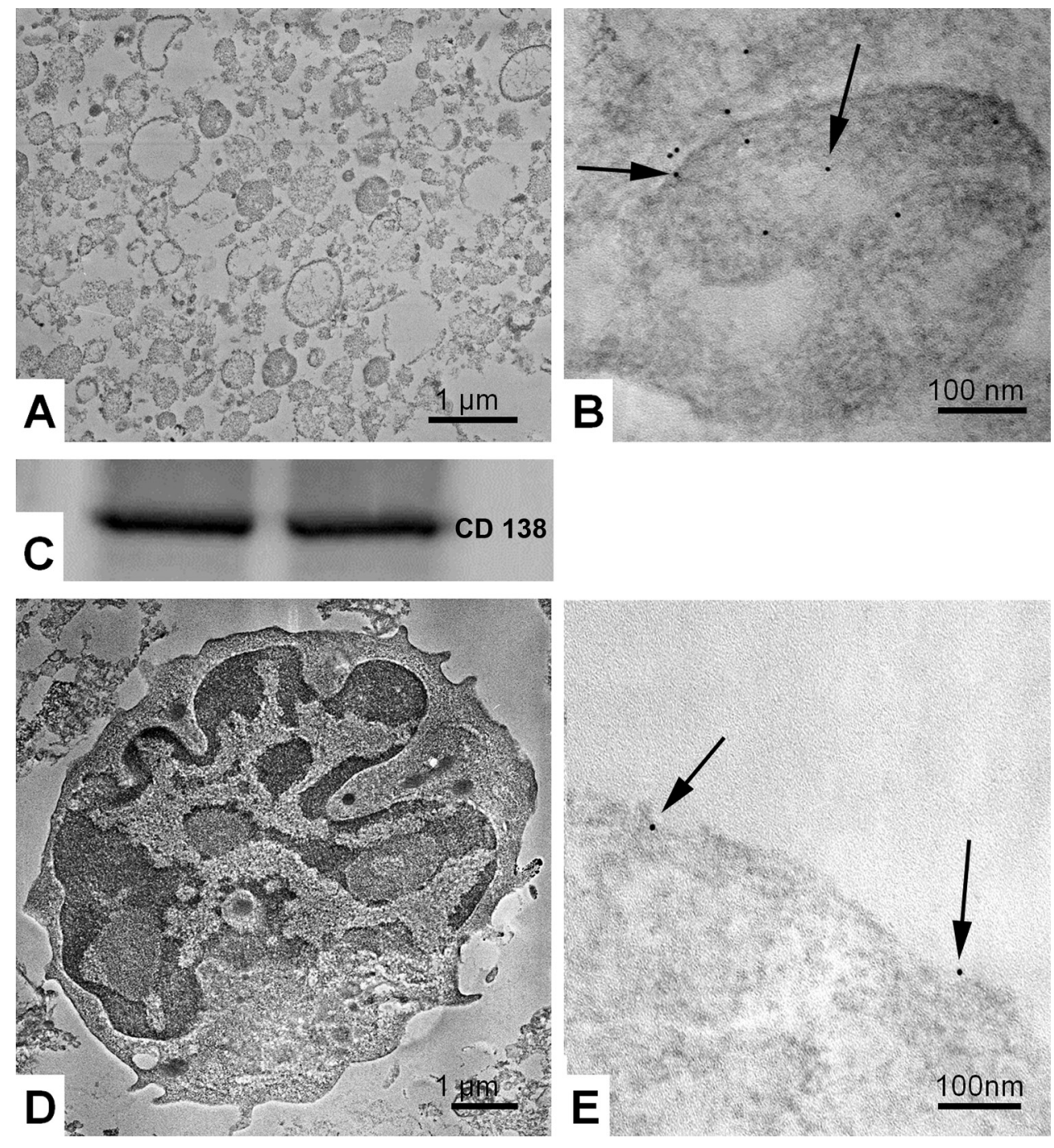

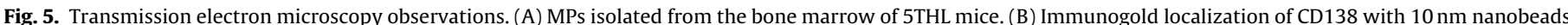

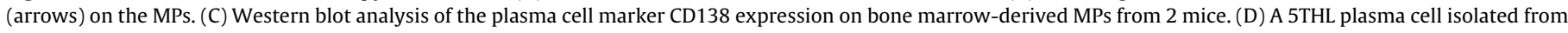
BM. (E) Immunogold localization of CD138 with $10 \mathrm{~nm}$ nanobeads (arrows) at the membrane surface of a 5THL plasma cells.

promote the development of osteolytic lesions (Libouban et al., 2003). Moreover, it had the capability to select an aggressive plasma cell line (5THL) that can reproduce a myeloma in a shorter period than the original cell line 5T2MM (Libouban et al., 2004).

Several methods for detection and quantification of MPs are available. Here, by using two methods, flow cytometry and TEM, we show that samples obtained from blood (Fig. 1A) and BM (Fig. 5A) are MP-enriched with homogenous size and different protein expression.

Recently, a number of studies report the involvement of MPs in tumor growth (Tavoosidana et al., 2011). It is now admitted that MPs play a role in various aspects of tumor progression: tumor microenvironment, angiogenesis, evasion of immune surveillance, metastasis, acquisition of aggressive phenotype and multi drug resistance (Muralidharan-Chari et al., 2010). In the present study, we found, at LMM, an increase of circulating MPs and MPs from BM. An increased level of MPs expressing tissue factor has been observed in untreated MM patients compared to healthy controls (Auwerda et al., 2011). In contrast to the present study conducted in mice, these authors mainly focused on the clinical impact of a high MP levels in relationship with venous thrombotic events since it is well established that these patients have at higher risk of developing arterio-venous thrombosis (Kristinsson, 2010). It should be noted that the 5TMM model mimics the marrow environment and bone lesions as observed in humans but other clinical characteristics of the disease such as thrombosis or renal lesions are never observed (Libouban et al., 2006). Indeed, neither platelet-derived MPs nor MPs expressing phosphatidylserine (i.e. with a procoagulant potential) were increased in the present study. In addition, a high level of MPs in cancer has been shown in vitro and in vivo to be correlated with tumor aggressiveness (Castellana et al., 2010; Ginestra et al., 1999). These observations are in agreement with our results as we found a high level of MPs at LMM. Of importance is the fact of the significant correlation between circulating MPs and M-protein. Thus, circulating MPs may be used as good diagnostic markers of the disease evolution.

In addition to the increased levels of total circulating MPs, those derived from erythrocytes and leukocytes were also enhanced when compared with control mice. In chronic lymphocytic leukemia, it was shown that MPs have mainly a platelet and leukemic B-cell origin (Ghosh et al., 2010). The high level of plateletderived MPs has been also observed in various types of cancer and it has been postulated that they may play a role in solid tumor progression and metastasis (Dashevsky et al., 2009; Kim et al., 2003). We did not observe such this phenomenon in our study. By analyzing the level of total circulating MPs and their phenotypic origin 
according to the stage of the disease, we expected to find intermediary results between controls and EMM. We also expected to find a phenotypic switch between EMM and LMM as previously reported in another hematologic malignancy (Ghosh et al., 2010). In the present murine model, the EMM was characterized by the onset of a very small level of M-protein (not shown), the absence of any osteolytic lesion on X-rays but a massive infiltration of tumor plasma cells in some bones (Libouban et al., 2004). The fact that early stage of myeloma decreased levels of circulating MPs is probably associated with blood cell count in these animals. Thus, alterations on the number and the function of blood cells have been reported in multiple myeloma patients. Concerning platelets and red blood cells, these alterations are associated with hypercoagulable state but also with thrombocytopenia and hemorrhagic complications. These effects may be associated with changes in hematological cells derived from BM (inducing anemia and thrombocytopenia) (Albarracin and Fonseca, 2011) but also with changes in blood viscosity and hemostasis (Elice and Rodeghiero, 2012). Moreover, it has been described that blood cells can be sequestered in thymus and BM of 5T2MM mouse model (Laronne-Bar-On et al., 2008) reducing the number of circulating MPs derived from these cells. Perhaps this EMM stage was too premature to detect enough MPs from plasma cells, suggesting that the high level of MPs observed at LMM could be a very useful biomarker of a progression of the disease and poor prognostic.

More interestingly, we found a high quantity of MPs from BM which corresponds to the local environment where tumor plasma cells grow. We managed to observe MPs by TEM with immunogold detection, coupled to western blotting. CD138 was strongly expressed on MPs isolated from the BM microenvironment, confirming the hypothesis that part of them were shed from the surface of malignant plasma cells. CD138 is a transmembrane heparin sulfate proteoglycan with an expression highly specific of plasma cells; it is not expressed on B or T lymphocytes (Wijdenes et al., 1996). Because of such a specific expression, CD138 is used as a standard marker in the diagnosis of MM (Bataille et al., 2006). Free circulating CD138 level is also correlated with tumor mass and it is implicated in the cell/cell adhesion process, in physical interaction with soluble factors and molecules form the extracellular matrix (Bataille et al., 2006; Dhodapkar et al., 1997).

In the 5T2MM model, differences have been shown in the expression of several markers like CD45 and CD138 at the stage level of the disease (Asosingh et al., 2003). At the quiescent stage (corresponding to our EMM), most MM cells are highly invasive and express CD45 ${ }^{+}$and $\mathrm{CD} 138^{-}$, whereas at the LMM, MM cells are more mature, less invasive with a $\mathrm{CD} 45^{-}, \mathrm{CD} 138^{+}$phenotype. In the present study, the CD138 expression was assessed only at the late stage where it was known that most of the cells are CD138

\section{Conclusion}

In conclusion, we provide evidence that, in LMM stage, circulating levels of MPs from mice were increased and that levels of BM-derived MPs expressing CD138 are correlated with the pathology severity. These MPs may play a critical role as vectors of deleterious biological messages leading to growth tumor. This finding may suggest that MPs could be new actors of the vicious circle involved in MM.

\section{Acknowledgments}

We thank SCIAM (Service Commun d'Imagerie et Analyses Microscopiques), Université d'Angers. This work was supported by a grant from Contrat Région Pays de la Loire (Bioregos2 program).

\section{References}

Abe, M., Hiura, K., Ozaki, S., Kido, S., Matsumoto, T., 2009. Vicious cycle between myeloma cell binding to bone marrow stromal cells via VLA-4-VCAM-1 adhesion and macrophage inflammatory protein-1alpha and MIP-1beta production. Journal of Bone and Mineral Metabolism 27, 16-23.

Abe, M., Hiura, K., Wilde, J., Shioyasono, A., Moriyama, K., Hashimoto, T., Kido, S. Oshima, T., Shibata, H., Ozaki, S., Inoue, D., Matsumoto, T., 2004. Osteoclasts enhance myeloma cell growth and survival via cell-cell contact: a vicious cycle between bone destruction and myeloma expansion. Blood 104, 2484-2491.

Agouni, A., Lagrue-Lak-Hal, A.H., Ducluzeau, P.H., Mostefai, H.A., Draunet-Busson, C., Leftheriotis, G., Heymes, C., Martinez, M.C., Andriantsitohaina, R., 2008 Endothelial dysfunction caused by circulating microparticles from patients with metabolic syndrome. American Journal of Pathology 173, 1210-1219.

Albarracin, F., Fonseca, R., 2011. Plasma cell leukemia. Blood Review 25, 107-112.

Angelucci, A., D’Ascenzo, S., Festuccia, C., Gravina, G.L., Bologna, M., Dolo, V., Pavan, A., 2000. Vesicle-associated urokinase plasminogen activator promotes invasion in prostate cancer cell lines. Clinical and Experimental Metastasis 18, $163-170$.

Asosingh, K., De Raeve, H., Van Riet, I., Van Camp, B., Vanderkerken, K., 2003. Multiple myeloma tumor progression in the 5T2MM murine model is a multistage and dynamic process of differentiation, proliferation, invasion, and apoptosis. Blood 101, 3136-3141.

Asosingh, K., Radl, J., Van Riet, I., Van Camp, B., Vanderkerken, K., 2000. The 5TMM series: a useful in vivo mouse model of human multiple myeloma. Hematology Journal 1, 351-356.

Auwerda, J.J., Yuana, Y., Osanto, S., de Maat, M.P., Sonneveld, P., Bertina, R.M., Leebeek, F.W., 2011. Microparticle-associated tissue factor activity and venous thrombosis in multiple myeloma. Thrombosis and Haemostasis 105, 14-20.

Bataille, R., Jego, G., Robillard, N., Barille-Nion, S., Harousseau, J.L., Moreau, P., Amiot M., Pellat-Deceunynck, C., 2006. The phenotype of normal, reactive and malignant plasma cells. Identification of many and multiple myelomas and of new targets for myeloma therapy. Haematologica 91, 1234-1240.

Castellana, D., Toti, F., Freyssinet, J.M., 2010. Membrane microvesicles: macromessengers in cancer disease and progression. Thrombosis Research 125 (Suppl. 2) S84L 88.

Choi, S.J., Cruz, J.C., Craig, F., Chung, H., Devlin, R.D., Roodman, G.D., Alsina, M., 2000 Macrophage inflammatory protein 1 -alpha is a potential osteoclast stimulatory factor in multiple myeloma. Blood 96, 671-675.

Croese, J.W., Vas Nunes, C.M., Radl, J., van den Enden-Vieveen, M.H., Brondijk R.J., Boersma, W.J., 1987. The 5T2 mouse multiple myeloma model: characterization of 5T2 cells within the bone marrow. British Journal of Cancer 56, $555-560$

Croucher, P.I., Shipman, C.M., Van Camp, B., Vanderkerken, K., 2003. Bisphosphonates and osteoprotegerin as inhibitors of myeloma bone disease. Cancer 97 $818-824$

Dashevsky, O., Varon, D., Brill, A., 2009. Platelet-derived microparticles promote invasiveness of prostate cancer cells via upregulation of MMP-2 production. International Journal of Cancer 124, 1773-1777.

Dhodapkar, M.V., Kelly, T., Theus, A., Athota, A.B., Barlogie, B., Sanderson, R.D., 1997 Elevated levels of shed syndecan-1 correlate with tumour mass and decreased matrix metalloproteinase- 9 activity in the serum of patients with multiple myeloma. British Journal of Haematology 99, 368-371.

Elice, F., Rodeghiero, F., 2012. Hematologic malignancies and thrombosis. Thrombosis Research 129, 360-366.

Ghosh, A.K., Secreto, C.R., Knox, T.R., Ding, W., Mukhopadhyay, D., Kay, N.E., 2010 Circulating microvesicles in B-cell chronic lymphocytic leukemia can stimulate marrow stromal cells: implications for disease progression. Blood 115, $1755-1764$.

Ginestra, A., Miceli, D., Dolo, V., Romano, F.M., Vittorelli, M.L., 1999. Membrane vesicles in ovarian cancer fluids: a new potential marker. Anticancer Research 19 3439-3445.

Giuliani, N., Colla, S., Morandi, F., Lazzaretti, M., Sala, R., Bonomini, S., Grano, M. Colucci, S., Svaldi, M., Rizzoli, V., 2005. Myeloma cells block RUNX2/CBFA1 activity in human bone marrow osteoblast progenitors and inhibit osteoblast formation and differentiation. Blood 106, 2472-2483.

Giuliani, N., Morandi, F., Tagliaferri, S., Colla, S., Bonomini, S., Sammarelli, G., Rizzoli, V., 2006. Interleukin-3 (IL-3) is overexpressed by T lymphocytes in multiple myeloma patients. Blood 107, 841-842.

Kim, C.W., Lee, H.M., Lee, T.H., Kang, C., Kleinman, H.K., Gho, Y.S., 2002. Extracellular membrane vesicles from tumor cells promote angiogenesis via sphingomyelin. Cancer Research 62, 6312-6317.

Kim, H.K., Song, K.S., Park, Y.S., Kang, Y.H., Lee, Y.J., Lee, K.R., Ryu, K.W., Bae, J.M., Kim, S., 2003. Elevated levels of circulating platelet microparticles, VEGF, IL-6 and RANTES in patients with gastric cancer: possible role of a metastasis predictor. European Journal of Cancer 39, 184-191.

Kristinsson, S.Y., 2010. Thrombosis in multiple myeloma. Hematology/the Education Program of the American Society of Hematology, 437-444.

Kukreja, A., Hutchinson, A., Dhodapkar, K., Mazumder, A., Vesole, D., Angitapalli, R. Jagannath, S., Dhodapkar, M.V., 2006. Enhancement of clonogenicity of human multiple myeloma by dendritic cells. Journal of Experimental Medicine 203, 1859-1865.

Laronne-Bar-On, A., Zipori, D., Haran-Ghera, N., 2008. Increased regulatory versus effector T cell development is associated with thymus atrophy in mouse models of multiple myeloma. Journal of Immunology 181, 3714-3724. 
Lee, J.W., Chung, H.Y., Ehrlich, L.A., Jelinek, D.F., Callander, N.S., Roodman, G.D., Choi, S.J., 2004. IL-3 expression by myeloma cells increases both osteoclast formation and growth of myeloma cells. Blood 103, 2308-2315.

Lemaire, M., Deleu, S., De Bruyne, E., Van Valckenborgh, E., Menu, E., Vanderkerken, K., 2011. The microenvironment and molecular biology of the multiple myeloma tumor. Advances in Cancer Research 110, 19-42.

Libouban, H., Moreau, M.F., Basle, M.F., Bataille, R., Chappard, D., 2003. Increased bone remodeling due to ovariectomy dramatically increases tumoral growth in the 5T2 multiple myeloma mouse model. Bone 33, 283-292.

Libouban, H., Moreau, M.F., Basle, M.F., Bataille, R., Chappard, D., 2004. Selection of a highly aggressive myeloma cell line by an altered bone microenvironment in the C57BL/KaLwRij mouse. Biochemical and Biophysical Research Communications 316, 859-866.

Libouban, H., Onno, C., Pascaretti-Grizon, F., Gallois, Y., Moreau, M.F., Baslé, M.F., Chappard, D., 2006. Absence of renal lesions in C57BL/KaLwRij mice with advanced myeloma due to 5T2MM cells. Leukemia Research 30, 1371-1375.

Martinez, M.C., Andriantsitohaina, R., 2011. Microparticles in angiogenesis: therapeutic potential. Circulation Research 109, 110-119.

Michigami, T., Shimizu, N., Williams, P.J., Niewolna, M., Dallas, S.L., Mundy, G.R., Yoneda, T., 2000. Cell-cell contact between marrow stromal cells and myeloma cells via VCAM-1 and alpha(4)beta(1)-integrin enhances production of osteoclast-stimulating activity. Blood 96, 1953-1960.

Mitsiades, C.S., McMillin, D.W., Klippel, S., Hideshima, T., Chauhan, D., Richardson, P.G., Munshi, N.C., Anderson, K.C., 2007. The role of the bone marrow microenvironment in the pathophysiology of myeloma and its significance in the development of more effective therapies. Hematology/Oncology Clinics of North America 21, 1007-1034.

Mostefai, H.A., Andriantsitohaina, R., Martinez, M.C., 2008. Plasma membrane microparticles in angiogenesis: role in ischemic diseases and in cancer. Physiological Research 57, 311-320.

Muralidharan-Chari, V., Clancy, J.W., Sedgwick, A., D’Souza-Schorey, C., 2010. Microvesicles: mediators of extracellular communication during cancer progression. Journal of Cell Science 123, 1603-1611.

Oshima, T., Abe, M., Asano, J., Hara, T., Kitazoe, K., Sekimoto, E., Tanaka, Y., Shibata, H., Hashimoto, T., Ozaki, S., Kido, S., Inoue, D., Matsumoto, T., 2005. Myeloma cells suppress bone formation by secreting a soluble Wnt inhibitor, sFRP-2. Blood 106, 3160-3165.
Pearse, R.N., Sordillo, E.M., Yaccoby, S., Wong, B.R., Liau, D.F., Colman, N., Michaeli, J., Epstein, J., Choi, Y., 2001. Multiple myeloma disrupts the TRANCE/osteoprotegerin cytokine axis to trigger bone destruction and promote tumor progression. Proceedings of the National Academy of Sciences of the United States of America 98, 11581-11586.

Peinado, H., Lavotshkin, S., Lyden, D., 2011. The secreted factors responsible for premetastatic niche formation: old sayings and new thoughts. Seminars in Cancer Biology 21, 139-146.

Roccaro, A.M., Hideshima, T., Raje, N., Kumar, S., Ishitsuka, K., Yasui, H., Shiraishi, N., Ribatti, D., Nico, B., Vacca, A., Dammacco, F., Richardson, P.G., Anderson, K.C., 2006. Bortezomib mediates antiangiogenesis in multiple myeloma via direct and indirect effects on endothelial cells. Cancer Research 66, 184-191.

Soleti, R., Benameur, T., Porro, C., Panaro, M.A., Andriantsitohaina, R., Martinez, M.C., 2009. Microparticles harboring Sonic Hedgehog promote angiogenesis through the upregulation of adhesion proteins and proangiogenic factors. Carcinogenesis 30, 580-588.

Standal, T., Abildgaard, N., Fagerli, U.M., Stordal, B., Hjertner, O., Borset, M., Sundan, A., 2007. HGF inhibits BMP-induced osteoblastogenesis: possible implications for the bone disease of multiple myeloma. Blood 109, 3024-3030.

Tavoosidana, G., Ronquist, G., Darmanis, S., Yan, J., Carlsson, L., Wu, D., Conze, T. Ek, P., Semjonow, A., Eltze, E., Larsson, A., Landegren, U.D., Kamali-Moghaddam, M., 2011. Multiple recognition assay reveals prostasomes as promising plasma biomarkers for prostate cancer. Proceedings of the National Academy of Sciences of the United States of America 108, 8809-8814.

Tian, E., Zhan, F., Walker, R., Rasmussen, E., Ma, Y., Barlogie, B., Shaughnessy Jr., J.D., 2003. The role of the Wnt-signaling antagonist DKK1 in the development of osteolytic lesions in multiple myeloma. New England Journal of Medicine 349, 2483-2494.

Tual-Chalot, S., Leonetti, D., Andriantsitohaina, R., Martinez, M.C., 2011. Microvesicles: intercellular vectors of biological messages. Molecular Interventions 11 88-94.

Wijdenes, J., Dore, J.M., Clement, C., Vermot-Desroches, C., 2002. CD138. Journal of Biological Regulators and Homeostatic Agents 16, 152-155.

Wijdenes, J., Vooijs, W.C., Clement, C., Post, J., Morard, F., Vita, N., Laurent, P., Sun, R.X., Klein, B., Dore, J.M., 1996. A plasmocyte selective monoclonal antibody (B-B4) recognizes syndecan-1. British Journal of Haematology 94, 318-323. 